\title{
Is there an increasing trend of risk-reducing prophylactic mastectomy procedure in preventing breast cancer among women?
}

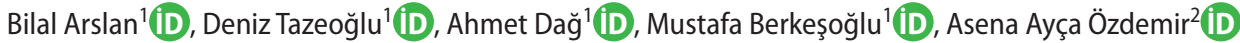 \\ 1 Department of General Surgery, Mersin University Faculty of Medicine, Mersin, Turkey \\ ${ }^{2}$ Department of Biostatistics, Mersin University Faculty of Medicine, Mersin, Turkey
}

\begin{abstract}
Objective: Prophylactic contralateral/bilateral mastectomy (PCM/PBM), as a risk-reducing mastectomy procedure, has a few evidence-based indications; however, there is an increasing trend in the total number of operations globally. Worldwide famous actress Angelina Jolie was detected to have BRCA-1 mutation and underwent a prophylactic bilateral mastectomy in 2013. The procedure was perceived as 'lifesaving' worldwide, which eventually led to a significant increase in BRCA gene mutation analysis and PCM/PBM. In this study, it was aimed to evaluate our risk-reducing PCM/PBM results.

Material and Methods: Twenty-seven patients underwent risk-reducing PCM/PBM between 2010-2018, but only 22 patients were included into the study. A retrospective analysis was carried out on demographics, family history, preoperative diagnoses, pathological findings, mastectomy details, reconstructive procedures, neoadjuvant chemotherapy, BRCA analysis, educational status, and mastectomy indications.

Results: Surgical indications or major reasons for surgery were as follows: BRCA-1 mutation $(n=5)$, BRCA-2 mutation $(n=3)$, malignant-like areas in magnetic resonance imaging $(n=2)$, lobular carcinoma in situ $(n=3)$ and intense anxiety $(n=9)$. Eighteen patients $(82 \%)$ underwent an additional reconstructive procedure via implantation or autologous tissue and four patients (18\%) underwent mastectomy only. PCM/PBM by years was as: 2010 ( $n=$ 1), $2011(n=0), 2012(n=1), 2013(n=2), 2014(n=1), 2015(n=2), 2016(n=3), 2017(n=4), 2018(n=8)$, which represents the recently increasing trend.

Conclusion: Risk-reducing PCM/PBM was performed in $59.1 \%$ of the patients $(n=13)$ for a significant medical reason, whereas for distress about a relapse or a new disease on the contralateral breast on the remaining $40.9 \%$ of the patients $(n=9)$. Evidence in the literature shows that risk-reducing mastectomy does not affect survival, although it lowers breast cancer incidence. Close surveillance, cancer screening, and chemoprevention methods should have priority.
\end{abstract}

Keywords: Risk-reducing mastectomy, breast cancer, BRCA1, BRCA2

Cite this article as: Arslan B, Tazeoğlu D, Dağ A, Berkeşoğlu M, Özdemir AA. Is there an increasing trend of risk-reducing prophylactic mastectomy procedure in preventing breast cancer among women? Turk J Surg 2021; 37 (4): 347-354.

\section{Corresponding Author}

Bilal Arslan

E-mail: bilalarslan84@hotmail.com

Received: 15.07 .2020

Accepted: 12.08 .202

Available Online Date: 31.12 .202

o Copyright 2021 by Turkish Surgical Society Available online at www.turkjsurg.com

DOI: $10.47717 /$ turkjsurg.2021.4963

\section{INTRODUCTION}

Breast cancer is the most common cancer in women both in Turkey and the world. One in every eight women has breast cancer in their life, and one in every 30 women dies due to reasons related to breast cancer (1). There has been a significant increase in the number of risk-reducing PCM/PBM (prophylactic contralateral/prophylactic bilateral mastectomy) globally as it doubled in the last ten years (2).

A study from the USA reports that 30-40\% of women with breast cancer consider having a PCM as a risk reducing procedure (3). Risk factors for contralateral breast cancer are BRCA-1 or 2 mutation, lobular carcinoma in-situ (LCIS), breast cancer history in the family, absence of hormone receptors, and diagnosis at a young age (4-6). PBM indications are BRCA or some other genetic mutations, LCIS, or prominent cancer history in the family (4).

Although breast-conserving surgery (BCS) is the standard treatment in early-stage breast cancer, mastectomy could be done in the form of nipple-sparing mastectomy (NSM) in eligible patients. PCM is performed as a risk-reducing procedure for these patients or patients with a genetic predisposition. In the modern era, surgical treatment preferences and methods are gradually evolving. From the 1990s to the 2020s, there has not been much change in BCS rates, but it is seen that PCM/ PBM rates increase while unilateral mastectomy preferences decrease (5). Women diagnosed with breast cancer mostly prefer to undergo PCM due to the risk of contralateral breast cancer. 
Similarly, women at high risk mostly prefer to undergo PBM even without any cancer diagnosis. PCM/PBM procedure has few evidence-based indications; however, there is an increasing trend in the total number of operations globally (6). Worldwide famous actress Angelina Jolie was detected to have BRCA-1 mutation and underwent PBM in 2013, and the risk-reducing procedure was perceived as 'lifesaving' worldwide, which eventually led to a significant increase in BRCA gene mutation analysis and PCM/PBM in the USA. Some reasons for an increase in the PCM/PBM procedure frequency are the exaggerated anxiety about developing contralateral breast cancer, better breast symmetry with reconstruction procedures, and high utilization rates of preoperative magnetic resonance imaging (MRI), which encourages mastectomy rate (7). This study aimed to analyze and present the results of our PCM/PBM results.

\section{MATERIAL and METHODS}

This study was approved by the ethics committee of the Mersin University (number: 2020/179). Of 1057 patients' records that were scanned, 27 patients who underwent risk-reducing PCM/ PBM between the years 2010-2018, aged 18-90 years, were identified. Of the 27 patients, 22 with sufficient and accurate medical records were included in the study and analyzed retrospectively. Demographics, family history, preoperative diagnosis, pathology results, mastectomy procedure, reconstructive procedures with implantation or autologous tissue, neoadjuvant chemotherapy (NCT), BRCA analysis rate, educational status, mastectomy indications, and follow-up period were analyzed retrospectively. All patients had mammography (MMG), ultrasonography (USG), and MRI in the preoperative period. The same team performed all surgical operations. Patients with bilateral synchronous/metachronous cancers were excluded.

Analyses were performed by Medicres- 'www.e-picos.com.' Descriptive statistics thereof were represented as frequency (n) and percentage (\%). Continuous variables were represented by mean $( \pm S D)$ or median (minimum-maximum).

\section{RESULTS}

Median age of the patients was 46 (31-61) years. Two patients (9\%) were diagnosed before the age of 35 . Nine patients (41\%) had a family history of breast cancer. Two patients had no lactation history, and the median lactation time was 11 (0-22) months. Descriptive properties of the patients are shown in Table 1.

CPM was performed for nine patients (41\%) in the same session, it was performed in different sessions for 12 patients (54.5\%), and BPM was performed for one patient (4.5\%). Prophylactic mastectomy was performed only for the left breast of 13 patients (59.1\%) and only for the right breast of eight patients (36.4\%); BPM was performed for one patient (4.5\%). Bilateral
NSM was performed for ten patients (45.5\%). Modified radical mastectomy (MRM) for the right breast and NSM for the left breast was performed in seven patients (31.8\%), MRM for the left breast, and NSM for the right breast was performed for five patients (22.7\%). Bilateral NSM was performed in the same session for two of the four patients. None of them had an implant or autologous reconstruction, right MRM and left NSM were performed in one patient, right MRM and left NSM were performed in one patient.

The mean value of tumor size on the right breast was $2.71 \pm$ $1.78(0.5-5.5) \mathrm{cm}$, the mean number of the metastatic lymph node on the right axillary was $2.14 \pm 0.69$ (1-3). The mean value of tumor size on the left breast was $3.69 \pm 2.14(0.5-7) \mathrm{cm}$, the mean number of the metastatic lymph node on the left axillary was $5.13 \pm 6.94$ (1-11). The distribution of molecular breast cancer subtypes is shown in Table 2.

Evaluation of four triple-negative patients by risk factors was as follows: BRCA-1 positive $(n=1)$, significant family history of breast cancer $(n=2)$, no other detectable risk factor apart from the unilateral diagnosis $(n=1)$.

Eighteen patients (82\%) underwent a reconstructive procedure, and four patients (18\%) did not undergo any additional surgery. Total 10 BRCA-1/2 mutation analyses were performed: one in 2010 (10\%), one in 2013 (10\%), one (10\%) in 2016, two in 2017 (20\%), five (50\%) in 2018.

Five patients were operated on because they had BRCA-1 gene mutation ( $n=5)$, three patients were operated on as they had BRCA-2 gene mutation $(n=3)$. Two patients had suspicious findings on MRI scans; BCS were recommended. However, as per the preference of the patients, NSM was performed. Mastectomy specimens were reported as invasive ductal carcinoma $(n=1)$ and benign $(n=1)$. Three patients were operated on as they had LCIS diagnosis. According to their expression, the main reason for the remaining nine patients' bilateral mastectomy was the intense anxiety they experienced. Six patients were operated on after receiving neoadjuvant chemotherapy as their locally advanced/advanced aggressive tumor characteristics. Five of these patients had PCM/PBM, and four had anxiety; one had a suspicion in the preoperative MRI scan. Thirteen patients (59.1\%) had operations for justifiable medical reasons. Nine patients (49.1\%) had PCM/PBM because they were anxious about a relapse. Only two of these nine patients had breast cancer in their family history. Out of nine patients who underwent PCM/ PBM, seven had bachelor's degrees (78\%), one (11\%) had a high school diploma, one (11\%) had a primary school diploma.

Pathology reports of the three (13.6\%) patients who underwent contralateral mastectomy without a diagnosis indicated malignancy, invasive ductal carcinoma $(n=2)$ and DCIS ( $n=1)$. Median follow-up time was 33 months (18-116) and none of them 
Table 1. Descriptive properties of the cases

\begin{tabular}{|c|c|c|c|c|c|c|c|}
\hline Case & Age & Year & Right Breast Diagnosis & $\begin{array}{l}\text { Left Breast } \\
\text { Diagnosis }\end{array}$ & $\begin{array}{l}\text { Indication For } \\
\text { CPM/BPM }\end{array}$ & Treatment & Family History \\
\hline Case 1 & 33 & 2015 & Invasive Lobular Carcinoma & Benign & Anxiety & $\begin{array}{l}\text { Right MRM } \\
\text { Left NSM }\end{array}$ & - \\
\hline Case 2 & 60 & 2017 & $\begin{array}{c}\text { Benign (Pathology: Invasive } \\
\text { Ductal Carcinoma) }\end{array}$ & $\begin{array}{l}\text { Invasive Ductal } \\
\text { Carcinoma }\end{array}$ & Suspicious MRI & Bilateral NSM & - \\
\hline Case 3 & 46 & 2013 & Benign & Mixed Carcinoma & Anxiety & $\begin{array}{l}\text { Right NSM } \\
\text { Left MRM }\end{array}$ & - \\
\hline Case 4 & 57 & 2017 & Invasive Ductal Carcinoma & Benign & BRCA-1(+) & Bilateral NSM & - \\
\hline Case 5 & 36 & 2013 & LCIS & Benign & LCIS & Bilateral NSM & - \\
\hline Case 6 & 37 & 2010 & Benign & $\begin{array}{c}\text { Benign } \\
\text { (Pathology: DCIS) }\end{array}$ & BRCA-1(+) & Bilateral NSM & - \\
\hline Case 7 & 56 & 2018 & DCIS & Benign & $\mathrm{BRCA}-2(+)$ & Bilateral NSM & + \\
\hline Case 8 & 60 & 2018 & Benign & $\begin{array}{l}\text { Invasive Ductal } \\
\text { Carcinoma }\end{array}$ & Anxiety & $\begin{array}{l}\text { Right NSM } \\
\text { Left MRM }\end{array}$ & - \\
\hline Case 9 & 55 & 2018 & Invasive Ductal Carcinoma & Benign & BRCA-1(+) & Bilateral NSM & + \\
\hline Case 10 & 37 & 2018 & Invasive Ductal Carcinoma & Benign & BRCA-1(+) & $\begin{array}{l}\text { Right MRM } \\
\text { Left NSM }\end{array}$ & - \\
\hline Case 11 & 40 & 2018 & Benign & $\begin{array}{l}\text { Invasive Ductal } \\
\text { Carcinoma }\end{array}$ & Anxiety & Bilateral NSM & + \\
\hline Case 12 & 50 & 2016 & Invasive Ductal Carcinoma & Benign & $\mathrm{BRCA}-2(+)$ & $\begin{array}{l}\text { Right MRM } \\
\text { Left NSM }\end{array}$ & + \\
\hline Case 13 & 44 & 2016 & Invasive Lobular Carcinoma & Benign & Anxiety & $\begin{array}{l}\text { Right MRM } \\
\text { Left NSM }\end{array}$ & - \\
\hline Case 14 & 61 & 2014 & Invasive Lobular Carcinoma & Benign & Anxiety & $\begin{array}{l}\text { Right MRM } \\
\text { Left NSM }\end{array}$ & - \\
\hline Case 15 & 55 & 2018 & $\begin{array}{c}\text { Benign (Pathology: Invasive } \\
\text { Ductal Carcinoma) }\end{array}$ & LCIS & BRCA-2(+) & Bilateral NSM & + \\
\hline Case 16 & 35 & 2017 & LCIS & Benign & LCIS & Bilateral NSM & - \\
\hline Case 17 & 43 & 2018 & Benign & $\begin{array}{l}\text { Invasive Ductal } \\
\text { Carcinoma }\end{array}$ & Anxiety & $\begin{array}{l}\text { Right NSM } \\
\text { Left MRM }\end{array}$ & + \\
\hline Case 18 & 58 & 2016 & Invasive Lobular Carcinoma & Benign & Anxiety & $\begin{array}{l}\text { Right MRM } \\
\text { Left NSM }\end{array}$ & - \\
\hline Case 19 & 52 & 2012 & Benign & $\begin{array}{l}\text { Invasive Ductal } \\
\text { Carcinoma }\end{array}$ & Suspicious MRI & $\begin{array}{l}\text { Right NSM } \\
\text { Left MRM }\end{array}$ & + \\
\hline Case 20 & 31 & 2018 & Invasive Ductal Carcinoma & Benign & Anxiety & $\begin{array}{l}\text { Right MRM } \\
\text { Left NSM }\end{array}$ & - \\
\hline Case 21 & 37 & 2015 & Benign & $\begin{array}{l}\text { Invasive Ductal } \\
\text { Carcinoma }\end{array}$ & BRCA-1(+) & $\begin{array}{l}\text { Right NSM } \\
\text { Left MRM }\end{array}$ & + \\
\hline Case 22 & 40 & 2017 & LCIS & Benign & LCIS & Bilateral NSM & + \\
\hline
\end{tabular}

had a recurrence. The numbers of PCM/PBM by years were as: $2010(n=1), 2011(n=0), 2012(n=1), 2013(n=2), 2014(n=1)$ $2015(n=2), 2016(n=3), 2017(n=4)$ and in $2018(n=8)$, which reflects the increasing trend in our center.

\section{DISCUSSION}

The frequency of risk-reducing PCM/PBM has increased rapidly worldwide in the last two decades. Although there is a risk of developing contralateral breast cancer in patients with breast 
Table 2. Distribution of molecular breast cancer subtypes

\begin{tabular}{|c|c|c|c|c|c|c|c|}
\hline & \multicolumn{5}{|c|}{ Right Luminal Type } & \multirow[b]{2}{*}{ Total } \\
\hline & & None & Basal like & Her2+ & Luminal-A & Luminal-B & \\
\hline \multirow{5}{*}{ 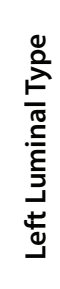 } & None & $1(4.5 \%)$ & $3(13.6 \%)$ & $1(4.5 \%)$ & $7(31.8 \%)$ & $1(4.5 \%)$ & $13(59.1 \%)$ \\
\hline & Basal like & $1(4.5 \%)$ & & & & & $1(4.5 \%)$ \\
\hline & Her2+ & $1(4.5 \%)$ & & & & & $1(4.5 \%)$ \\
\hline & Luminal-A & $4(18.2 \%)$ & & & & & $4(18.2 \%)$ \\
\hline & Luminal-B & $3(13.6 \%)$ & & & & & $3(13.6 \%)$ \\
\hline \multicolumn{2}{|c|}{ Total } & $10(45.5 \%)$ & $3(13.6 \%)$ & $1(4.5 \%)$ & $7(31.8 \%)$ & $1(4.5 \%)$ & $22(100.0 \%)$ \\
\hline
\end{tabular}

cancer, it is dramatized by both patients and physicians. USAbased studies report that $30-40 \%$ of the patients who have breast cancer diagnosis consider having a prophylactic contralateral mastectomy as a risk-reducing procedure, and 15-20\% of them undergo prophylactic mastectomy + reconstruction (3). In our study, the rate of having a prophylactic mastectomy in a population of 1057 patients operated on in the last decade was approximately $2 \%$. However, we did not collect data regarding their opinions about prophylactic mastectomy in this review.

A prophylactic mastectomy patient's general profile is anxious, young, with a breast cancer family history, and with suspicious MR findings. It is suggested that surgeons significantly affect the decision-making process of the patients (5). Many surgeries are not in line with medical indications and mainly aim to relieve patients' anxiety and concerns. Many breast study communities published results suggesting various recommendations for prophylactic mastectomy, strictly advised that it should not be carried out without indication (8). Women with breast cancer may often request prophylactic mastectomy due to the concern that new cancer may develop in the breast tissue on the healthy side as well. In our study, $42 \%$ of the patients underwent prophylactic mastectomy operation due to anxiety and fear without justifiable medical evidence. In their prospective randomized study, Parker et al. measured the quality of life and patient satisfaction; they included 50 prophylactic contralateral mastectomies out of 288 patients who had a mastectomy. They observed that breast cancer patients were highly anxious about relapse or developing new cancer in the contralateral breast. At the same time, postoperative body appearance perceptions were mostly found worse than preoperative. Every woman would prefer her breasts to match one another. After PCM operation, the patient satisfaction rate is generally lower than after PBM operation (9). We did not collect any data about evaluating the patients' quality of life and body appearance perception after surgery. However, the high rate of patient anxiety and fear in our study ( $n=9,40.9 \%)$ is compatible with the studies in the literature. Patients who were a candidate for PCM should be thoroughly evaluated in many respects.
For a woman with breast cancer without any detectable genetic mutation, the risk of developing breast cancer in her contralateral breast is $0.3 \%$ to $0.6 \%$ per year $(10,11)$. However, high-risk women, such as a family history of breast cancer, personal risk factors, LCIS diagnosis, medically reported genetic mutation (especially BRCA1-2) history, usually prefer PCM/PBM rather than surveillance and screening programs. Many studies have reported that the risk-reducing PCM/PBM procedure could not provide a significant reduction of survival unless there was LCIS or reported deleterious genetic mutation, but it might decrease the incidence of breast cancer (12-15). In the COCHRANE study by Carbine et al., 61 observational studies retrospectively analyzed that PCM reduced tumor recurrence without survival advantage. There is not a randomized study on this subject yet. Each patient should be evaluated individually to reach the best decision (16). In our study, no patients had a recurrence in the follow-up period. Although the number of patients and data was limited to reach an absolute conclusion about recurrence, the absence of recurrence was compatible with many previous studies in the literature. Despite our limited follow-up period, none of our patients lost their lives during this period.

The majority (77\%) of the patients who underwent PCM/PBM operation due to anxiety have a bachelor's degree. The rate of prophylactic mastectomy among well-educated women and women with a higher socioeconomic standard was relatively high. We could not achieve statistically significant results due to the limited number of patients, and we consider it clinically significant. Our results were consistent with the results of previous studies (5).

Six patients were treated with neoadjuvant chemotherapy as their locally advanced/advanced and aggressive tumor characteristics. PCM/PBM was performed in four of these six patients due to anxiety; one had BRCA-2 gene mutation, and one had preoperative suspicious MRI findings. Patients receiving neoadjuvant chemotherapy were aware that they were referred to oncology because of their aggressive tumor characteristics and large tumor sizes. Anxiety and fear of these patients were observed to be at higher levels than other patients. These patients had a great tendency to undergo a PCM operation to prevent new tumor oc- 
Table 3. Number of prophylactic mastectomy operations

\begin{tabular}{|l|c|c|}
\hline & $\mathbf{n}$ & $\%$ \\
\hline 2010 & 1 & 4.5 \\
\hline 2011 & 0 & 0 \\
\hline 2012 & 1 & 4.5 \\
\hline 2013 & 2 & 9 \\
\hline 2015 & 1 & 4.5 \\
\hline 2016 & 2 & 9 \\
\hline 2017 & 3 & 13.5 \\
\hline 2018 & 4 & 18 \\
\hline Total & 8 & 36 \\
\hline
\end{tabular}

currence at contralateral breast or tumor recurrence. Only two of the six patients in our study underwent PCM/PBM for a justifiable medical reason. There is no exact data on this subject in the literature. Although the limited number of patients did not allow us to draw any statistically significant results, the high rates of bilateral mastectomy due to anxiety in our locally advanced/advanced cancers may be underlined. We consider that the high PCM/PBM rate in our clinic is solely due to patients' anxiety.

In Fairbairn's study of 100 patients who had undergone PCM, $42 \%$ of the patients were operated on due to a justifiable medical indication. Besides, 13\% of patients underwent PCM operation due to suspicious MRI findings, and only $8 \%$ of patients' postoperative pathology reports were malignant (1). In our study, $59.1 \%$ of the patients were operated on for a justifiable medical reason. In $40.1 \%$ of the patients, PCM/PBM was performed without a justifiable medical reason due to anxiety about relapse. However, it should be remarked that such patients with diagnosed breast cancer do have a higher risk of developing breast cancer in the contralateral breast than the average population. Also, two of the patients had a family history of breast cancer.

Risk-reducing PCM/PBM was performed on one or two patients annually between 2010-2014, increased every year in line with the global trend until 2018, and was performed on eight patients (36\%) in 2018 (Table 3, Figure 1).

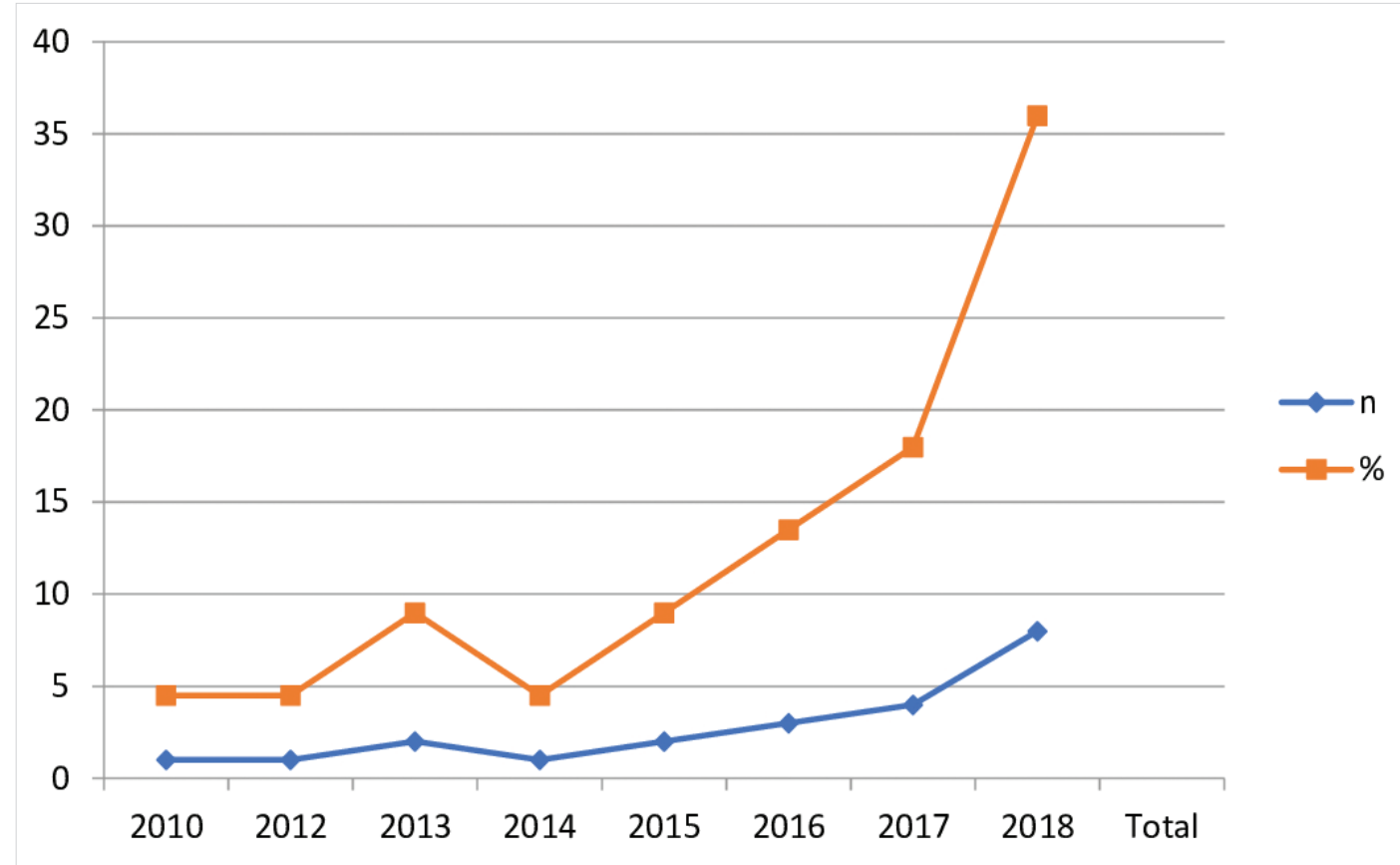

Figure 1. Number of mastectomy operations. 
The frequency of BRCA mutation analysis has also increased significantly in the last two decades. There can be underlying reasons thereof. In our opinion, the most critical factor might be that the PCM/PBM lowered the price of the test and the coverage of the BRCA analysis by the Social Security Institution in Turkey. Traditionally, the rate of testing had been lower among women with low income (4). Furthermore, in recent years, the frequency of prophylactic mastectomy has increased. Besides, after the famous movie star Angelina Jolie announced that she had risk-reducing bilateral prophylactic mastectomy + reconstruction due to having BRCA-1 mutation, the frequency of BRCA mutation analysis and PCM/PBM increased all over the world, which was defined as the Angelina Jolie effect $(17,18)$. This procedure, which was launched as a life-saver after the announcement, has become even more popular. It has generally become a preferred method among women who are well educated, with high socioeconomic status and have anxiety with a family history of breast cancer (19).

About $10 \%$ of breast cancers are associated with germline genetic mutations such as TP53, BRCA-1, BRCA-2, CDH1, STK11, and PTEN. BRCA-1 and BRCA-2, breast-ovarian syndromes are responsible for approximately one-third of them. The overall lifetime risk of developing breast cancer (up to 80 ) is approximately $72 \%$ in BRCA-1 and approximately $69 \%$ in BRCA-2. Breast cancer that develops in BRCA mutation carriers is often bilateral and multicentric. In BRCA-1 carriers, breast cancer develops at an earlier age as opposed to BRCA-2 carriers, especially before the age of 50 and being a triple-negative aggressive type (20). In our study, the BRCA mutation test was run in ten patients and detected as positive in eight patients. Five of the patients had BRCA-1 gene mutation, and three patients had BRCA-2 gene mutation. PBM operation was performed in one (4.5\%) patient with BRCA-1 mutation, and PCM operation was performed in seven (31.5\%) patients. Two of the patients requested prophylactic mastectomy to relieve their anxiety, even though no deleterious mutation was detected in the BRCA test.

Various strategies are used to reduce or eliminate the risk of developing hereditary breast cancer. Close surveillance and strict follow-up, including prominently MRI (annual or every six months), MMG, USG, and physical examination, should be started from the age of 25 or the earliest breast cancer age in the family. Chemoprevention is proposed as an alternative method. However, there is not enough evidence to prove selective estrogen receptor modulators, and aromatase inhibitors prevent or reduce breast cancer risk in BRCA carriers. Bilateral salpingooferectomy is recommended at the age of 35-40 years after patients complete their planned deliveries (21). In a study conducted by Marta D'Alonzo et al., attentive close surveillance and observation for high-risk patients in breast cancer development have been shown to have high patient satisfaction rates and reduce patients' anxiety about cancer.
On the other hand, prophylactic contralateral/bilateral mastectomy + reconstructive procedure has been suggested to increase patient satisfaction, yet cosmetic results reduce patient satisfaction. Bilateral salpingooferectomy has also been shown to decrease breast and ovarian cancer incidence in BRCA1-2 mutation carriers. One of our patients underwent bilateral salpingooferectomy after delivery.

This procedure also reduces the risk of breast cancer by $50 \%$ (19). In our study, BRCA1-2 genetic mutation analysis was applied to ten patients in total, one (10\%) in 2010, one (10\%) in 2013 , one (10\%) in 2016, two (20\%) in 2017, and five (50\%) in 2018. Analyses for other hereditary breast cancer syndromes were not performed. Although the numbers of our patients were limited, the mutation analysis rate has increased over the years. It was considered compatible with the trend in the world in recent years.

LCIS does not usually turn into cancer, but it is a risk factor for invasive breast cancer. Therefore, removing the LCIS lesion is not beneficial for the patient. These patients are recommended chemoprevention, close surveillance, or PBM (22). Patients with a prominent breast cancer family history and widespread anxiety, as in our study, may prefer PBM. In our study, one patient (4.5\%) had prophylactic PCM due to both DCIS and BRCA-2 positivity, and three patients (13.5\%) had PCM due to LCIS.

Suspicious MRI findings may not be correlated with precancerous or cancerous tissue in the final histopathological examination and urge both physician and patient to unnecessary breast operation (1). Although the number of patients was not sufficient to discuss that issue in our study, invasive ductal carcinoma was diagnosed in one of the patients who was operated on due to suspicious findings on MRI.

Specimens from three patients (13.5\%) of all PCM patients were reported as malignant as a result of the final pathology. one of these had BRCA-1 gene mutation, one patient had BRCA-2 gene mutation, and one patient had no other risk factor other than the presence of cancer on the contralateral breast. These results were compatible with the studies in the literature (6).

Twelve of twenty-two patients who underwent PCM/PBM had an implant, six patients had an autologous reconstructive procedure, and the remaining four patients (18\%) did not undergo any additional surgery. The implant or reconstructive procedure was performed for eight patients in the same session following the mastectomy operation, and ten of them later on in a separate session. The implant or reconstructive procedure was not applied simultaneously with chemotherapy to regard patient-specific considerations and patient preference; it may delay chemotherapy and might disrupt the cancer treatment. These findings were compatible with the findings in the literature (23). However, in our study, no evaluation was made regarding the patients' postoperative satisfaction status and how they perceived their body 
appearance. Previous studies report that up to 17\% of patients are not satisfied with their body's final appearance and that they would not prefer such an operation if they could decide now that they can see the results. As a result of PBM, some patients have declared that they had a negative perception of their physiology, sexual health, and appearance of their bodies (24). In a study published by Qin et al. in 2018, it was highlighted, as in many previous studies, that breast implants and reconstructions performed in the same session positively affect sexual health and the perception of body appearance and increased patient satisfaction and quality of life. They also suggested that having an implant or reconstructive operation in the same session with mastectomy does not affect oncological outcomes (25). We believe that these developments have increased the trend towards risk-reducing prophylactic mastectomy, and this trend will escalate. Therefore, we think that all patients should be consulted with the plastic surgery unit before the PCM/PBM procedure. Our study had some limitations including its small sample size and being conducted retrospectively at a single-center.

\section{CONCLUSION}

Although PCM/PBM reduces breast cancer incidence, it has no proven reducing effect on survival. The patient's anxiety should be eliminated by providing all kinds of options available for the patient by the physician, and the patient should be able to make decisions in the best setting. To prevent risk-reducing mastectomy without indication, we suggest a thorough and patient-based evaluation regarding patient preference and a multidisciplinary approach that includes general surgeons, medical oncologists, plastic and reconstructive surgeons, radiologists, and psychiatrists.

Ethics Committee Approval: This study approval was obtained from Mersin University Clinical Research Ethics Committee (Decision No: 2019-563, Date: 19.12.2019).

Peer-review: Externally peer-reviewed.

Author Contributions: Concept - A.D., B.A.; Design - A.D., B.A., D.T.; Supervision - A.D., B.A., D.T.; Data Collection and/or Processing - A.A.Ö., A.D., B.A.; Analysis and/or Interpretation - B.A., A.A.Ö., A.D., D.T.; Literature Search - B.A., M.B.; Writing Manuscript - B.A., M.B., A.A.Ö.; Critical Reviews - A.D., B.A., M.B.

Conflict of Interest: The authors have no conflicts of interest to declare.

Financial Disclosure: The authors declared that this study has received no financial support.

\section{REFERENCES}

1. Fairbairn K, Cervantes A, Rayhrer C, Steen S. Trends in contralateral prophylactic mastectomy. Aesthetic Plast Surg 2020; 44(2): 323-9. [CrossRef]

2. Nealon KP, Sobti N, Gadd M, Specht M, Liao EC. Assessing the additional surgical risk of contralateral prophylactic mastectomy and immediate breast implant reconstruction. Breast Cancer Res Treat 2020; 179(2): 255-65. [CrossRef]
3. Wong SM, Freedman RA, Sagara Y, Aydogan F, Barry WT, Golshan M. Growing use of contralateral prophylactic mastectomy despite no improvement in long-term survival for invasive breast cancer. Ann Surg 2017 265(3): 581-9. [CrossRef]

4. Kruper L, Kauffmann RM, Smith DD, Nelson RA. Survival analysis of contralateral prophylactic mastectomy: a question of selection bias. Ann Surg Oncol 2014 21(11): 3448-56. [CrossRef]

5. Arpino G, Bardou VJ, Clark GM, Elledge RM. Infiltrating lobular carcinoma of the breast: tumor characteristics and clinical outcome. Breast Cancer Res 2004; 6(3): R149-56. [CrossRef]

6. Yi M, Meric-Bernstam F, Middleton LP, Arun BK, Bedrosian I, Babiera GV. Predictors of contralateral breast cancer in patients with unilateral breast cancer undergoing contralateral prophylactic mastectomy. Cancer 2009 115(5): 962-71. [CrossRef]

7. Evers C, Fischer C, Dikow N, and Schott S. Familial breast cancer: Genetic counseling over time, including patients' expectations and initiators considering the Angelina Jolie effect PLoS One 2017; 12(5): e0177893. [CrossRef]

8. Guillem JG, Wood WC, Moley JF, Berchuck A, Karlan BY, Mutch DG. ASCO/SSO review of the current role of risk-reducing surgery in common hereditary cancer syndromes. J Clin Oncol 2006; 24(28): 4642-60. [CrossRef]

9. Parker PA, Peterson SK, Shen Y, Bedrosian I, Black DM, Thompson AM. Prospective study of psychosocial outcomes of having contralateral prophylactic mastectomy among women with nonhereditary breast cancer. J Clin Oncol 2018; 36(25): 2630-38. [CrossRef]

10. Chowdhury M, Euhus D, Onega T, Biswas S, Choudhary PK. A model for individualized risk prediction of contralateral breast cancer. Breast Cancer Res Treat 2017; 161(1): 153-60. [CrossRef]

11. Reiner AS, John EM, Brooks JD, Lynch CF, Bernstein L, Mellemkjæer L. Risk of a synchronous contralateral breast cancer in noncarriers of BRCA1 and BRCA2 mutations with a family history of breast cancer: a report from the Women's Environmental Cancer and Radiation Epidemiology Study. J Clin Oncol 2013; 31 (4): 433-9. [CrossRef]

12. D'Alonzo M, Piva E, Pecchio S, Liberale V, Modaffari P, Ponzone R. Satisfaction and impact on quality of life of clinical and instrumental surveillance and prophylactic surgery in BRCA-mutation carriers. Clin Breast Cancer 2018; 18(6): e1361-e1366. [CrossRef]

13. Rutgers EJT. Is prophylactic mastectomy justified in women without BRCA mutation? The Breast 2019; 48 Suppl 1: 62-4. [CrossRef]

14. Angelos P, Bedrosian I, Euhus DM, Herrmann VM, Katz SJ, Pusic A. Contralateral prophylactic mastectomy: challenging considerations for the surgeon. Ann Surg Oncol 2015; 22(10): 3208-12. [CrossRef]

15. Franceschini G, Riccardo Masetti MD. Bilateral risk-reducing mastectomy in BRCA mutation carriers: A difficult decision-making. Breast J 2019; 25(3): 564-65. [CrossRef]

16. Carbine NE, Lostumbo L, Wallace J, Ko H. Risk-reducing mastectomy for the prevention of primary breast cancer. Cochrane Database Syst Rev 2018; 4(4): CD002748. [CrossRef]

17. Liede A, Cai M, Crouter TF, Niepel D, Callaghan F, Evans DG. Riskreducing mastectomy rates in the US: a closer examination of the Angelina Jolie effect. Breast Cancer Res Treat 2018; 171(2): 435-42. [CrossRef]

18. Kmietowicz Z, Angelina Jolie's mastectomy triggered a sharp rise in gene testing. 2016; 355: i6702. [CrossRef]

19. Roberts MC, Dusetzina SB. The effect of a celebrity health disclosure on demand for health care: trends in BRCA testing and subsequent health services use. J Community Genet 2017; 8(2): 141-6. [CrossRef] 
20. Dumitrescu RG. Interplay between genetic and epigenetic changes in breast cancer subtypes. Methods Mol Biol 2018; 1856: 19-34. [CrossRef]

21. National Comprehensive Cancer Network (NCCN). Clinical Practice Guidelines in Oncology: Genetic/Familial High-Risk Assessment: Breast and Ovarian. Available from: https://www.nccn.org/professionals/physician_gls/default.aspx (Accessed date: 2018). [CrossRef]

22. Miller ME, Muhsen S, Zabor EC, Flynn J, Olcese C, Giri D, et al. Risk of contralateral breast cancer in women with ductal carcinoma in situ associated with synchronous ipsilateral lobular carcinoma in situ. Ann Surg Oncol 2019; 26(13): 4317-25. [CrossRef]
23. Cabanuz MA, Del Amo MDA, Barles AN, Sanchez ATG. Influence of radiotherapy on immediate breast reconstruction after skin-sparing mastectomy. Before or after: does it matter? Cir Esp 2019; 97(3): 15661. [CrossRef]

24. Frost MH, Slezak JM, Tran NV, Williams Cl, Johnson JL, Woods JE. Satisfaction after contralateral prophylactic mastectomy: the significance of mastectomy type, reconstructive complications, and body appearance. J Clin Oncol 2005; 23(31): 7849-56. [CrossRef]

25. Qin Q, Tan Q, Lian B, Mo Q, Huang Z, Wei C. Postoperative outcomes of breast reconstruction after mastectomy: a retrospective study. Medicine (Baltimore) 2018; 97(5): e9766. [CrossRef]

\title{
ORIJINAL ÇALIŞMA-ÖZET
}

Turk J Surg 2021; 37 (4): 347-354

\section{Kadınlarda meme kanserini önlemede risk azaltıcı profilaktik mastektomi prosedürünün artan bir eğilimi var mıdır?}

\author{
Bilal Arslan ${ }^{1}$, Deniz Tazeoğlư ${ }^{1}$, Ahmet Dağ ${ }^{1}$, Mustafa Berkeşoğlư ${ }^{1}$, Asena Ayça Özdemir \\ ${ }^{1}$ Mersin Üniversitesi Tıp Fakültesi, Genel Cerrahi Anabilim Dalı, Mersin, Türkiye \\ ${ }^{2}$ Mersin Üniversitesi Tıp Fakültesi, Biyoistatistik Anabilim Dalı, Mersin, Türkiye
}

\section{ÖZET}

Giriş ve Amaç: Risk-azaltıcı kontralateral/bilateral profilaktik mastektomi prosedürü için kanıta dayalı çok az endikasyon vardır. Bu kısıtlı endikasyonlara rağmen tüm dünyada uygulanma sıklığı giderek artmaktadır. Bu ameliyat, BRCA-1 mutasyonu taşıyıcılığı nedeniyle bilateral profilaktik mastektomi geçiren ünlülerden dolayı tüm dünyada hayat kurtarıcı olarak lanse edilmiş, ABD'de BRCA gen mutasyon analiz sıklığı ve kontralateral/bilateral profilaktik mastektomi uygulanma sıklığı artmıştır. Bu çalışmada kliniğimizdeki kontralateral/bilateral profilaktik mastektomi uygulama sonuçlarını incelemeyi amaçladık.

Gereç ve Yöntem: 2010-2018 yılları arasında kontralateral/bilateral profilaktik mastektomi uygulanan 27 hastadan verilerine ulaşılabilen 22'si çalışmaya dahil edildi. Bu hastaların demografik verileri, aile hikayeleri, preop tanıları, tümör özellikleri, uygulanan prosedür, implant veya rekonstruktif işlem uygulanma durumu, neoadjuvan KT alma durumları, BRCA bakılma oranları, eğitim durumları ve endikasyonları retrospektif olarak incelendi.

Bulgular: Cerrahi endikasyonlar veya cerrahi prosedür uygulanmasının başlıca gerekçeleri şunlardır: BRCA-1 mutasyonu $(n=5), B R C A-2$ mutasyonu $(n=3)$, manyetik rezonans görüntülemede malign benzeri alanlar $(n=2)$, lobüler karsinoma in situ $(n=3)$ ve yoğun kaygı $(n=9)$ 'dır. 18 hastaya (\%82) implantasyon veya otolog doku yoluyla ek bir rekonstrüktif prosedür uygulandı ve 4 hastaya (\%18) sadece mastektomi yapıldı. Yıllara göre PCM/PBM uygulanma sıklığı şöyledir: $2010(n=1), 2011(n=0), 2012(n=1), 2013(n=2), 2014(n=1), 2015(n=2), 2016(n=3), 2017(n=4), 2018(n=$ 8). Bu da son zamanlarda artan eğilimi temsil ediyor.

Sonuç: Hastaların \%59,1 (13) tanesi kabul edilebilir tıbbi bir gerekçe ile opere edilmişlerdir. $\% 40,9$ 'u, hastalık nüks etme endişesi ve korkusuyla risk-azaltıcı kontralateral/bilateral profilaktik mastektomi geçirmiştir. Kontralateral/bilateral profilaktik mastektomi meme kanseri insidansını azaltsa da, surviye ek bir katkısının olmadığı birçok çalışmada gösterilmiştir. Yakın takip, tarama ve kemoprevensiyon yöntemleri öncelikli olmalıdır.

Anahtar Kelimeler: Risk-azaltıcı mastektomi, meme kanseri, BRCA1, BRCA2

Doi: 10.47717/turkjsurg.2021.4963 